\title{
Aspects Regarding the Commercial Profitability of the Companies from Localities on the Coastal Area of Tulcea County
}

\author{
Kamer-Ainur Aivaz, Dragoş-Florian Vintilă, Mari-Isabella Stan, Ionela Ionițiu \\ and Diana-Doina Ţenea
}

\begin{abstract}
The purpose of this paper is the analysis of the business environment in the coastal area of Tulcea county, by administrative-territorial units, with the help of a synthetic indicator to appreciate the economic-financial performance, the profit rate. The analysis was performed for year 2018, the economic phenomena and processes being captured at the spatial level. The results obtained from this work support the strategy for the rehabilitation of the coastal zone in order to increase the economic performances by adopting policies corresponding to the new realities.
\end{abstract}

Keywords - business environment, coastal area, economic performance.

\section{INTRODUCTION}

The development of coastal areas is based on the principle of sustainable development that requires the planning and protection of these areas, taking into account the economic and social development related to the presence of the sea, in order to preserve the fragile biological and ecological balance and the specific landscapes. Therefore, the development of the Romanian coastal zone takes into account the interactions between the social, environmental and economic factors in the area, and not only, sustainable development itself has "enriched" by adding a cultural pillar to the three traditional ones - economic, social and environmental [5], [6].

The economic activity of Tulcea county is characterized by a diversified industry, an agriculture based more and more on private property, a trade favored by the existence of all categories of means of transport (road, rail, river, maritime and air), as well as through an accentuated tourist activity, to capitalize on the beauty of the Danube Delta.

Along the Tulcea coast and within the Danube Delta natural reserve therea are several localities, from north to south: C.A. Rosetti, the town of Sulina, as well as the communes of Sfântu Gheorghe, Murighiol and Jurilovca.

\section{RESEARCH FRAMEWORK}

In this context, it is necessary to know the impact of the economic activities on the used areas, which is why the analysis of the business environment in the coastal area of 


\section{sciendo}

Tulcea County, by administrative-territorial units, will be carried out, with the help of a synthetic indicator of appreciation of the economic-financial performance, the profit rate.

Profit analysis can provide information on the absolute profitability of the company. For both the internal diagnosis and the external users of the information regarding the company, the knowledge of the capacity to produce absolute profit is not sufficiently representative. As a result, it is necessary to compare the mass of the profit with other sizes, in particular with the quantities that express the effort made to obtain the mass of the profit, resulting in rates of profitability that, from the point of view of the analysis, have a higher information capacity.

The expression of the relative profitability is realized through a system of rates that expresses the capacity of the company to ensure, with the help of the available resources, the remuneration of the invested capital. This system of rates is determined as a ratio between the economic and financial effects obtained by the company and the efforts made to obtain them.

The importance of knowing the rates of return / profitability derives from:

$\checkmark$ Favours the orientation of the production structure on products, branches and subbranches, in the sense of finding those that offer the greatest advantage because the economic flows are permanently redirected, rendering the economic activities an unequal development;

$\checkmark \quad$ Stimulates the rational use of resources;

$\checkmark$ Favours market segmentation and differentiation of business strategies.

In the economic-financial analysis of the results of the enterprise, the rates of profitability allow us to make comparisons between groups of companies, of activities, as well as spatial comparisons. Depending on the elements taken into account for their determination, the economic theory and practice operate with several types of rates of profitability: rates of expenditures versus incomes; rates of commercial profitability (profitability rates); rates of profitability on consumed resources; rates of economic profitability (also called yield rates); rates of financial profitability (also called rates of global profitability).

The initial database, provided by database of institutions with competencies in the field, was formed from 18569 companies in the records of Tulcea County administration, of which 7618 were in operation in 2018. By refining the data, selecting the localities Sulina, C.A. Rosetti, Jurilovca, Murighiol and Sfântu Gheorghe, administrative-territorial units belonging to the coastal area, there were 76 companies registered in Sulina, 2 companies in C.A Rosetti, 46 companies in Jurilovca, 56 in Murighiol and 18 in Sfântu Gheorghe.

The efficiency of the invested capital, of all the material and financial resources involved in the activity of the company, are presented by the rate of economic profitability. In the specialized literature, the rate of economic profitability can be calculated according to several models, in this study we opted for the following way of expression:

Operating profit rate $=\frac{\text { operating profit }}{\text { turnover }} x 100$

In the formula for calculating the rate of economic profitability, the use of the operating result or the gross operating result in the numerator is dictated by the interests in considering or not the depreciation or supply policy of the enterprise.

Systematizing information and calculation of statistical indicators was achieved with the help of the SPSS software [3]. The starting point of the study was the statistical description of the revenues and expenses of the operation, as well as the turnover with the 
following statistical indicators: the average level (mean), the number of companies $(\mathrm{N})$, the cumulative value of the financial indicator at the territorial unit level (Sum), the structure of the financial indicator at the territorial unit level (\% of Total Sum) and the structure of the number of companies (\% of Total N) [1],[2] (Table 1).

Table. 1. Statistical description of turnover, operating expenses and revenues in 2018 for companies in the coastal area of Tulcea County

\begin{tabular}{|c|c|c|c|c|}
\hline \multicolumn{2}{|l|}{ Localities } & Turnover (lei) & $\begin{array}{c}\text { Operating } \\
\text { expenses (lei) }\end{array}$ & $\begin{array}{c}\text { Operating } \\
\text { revenues (lei) }\end{array}$ \\
\hline \multirow{5}{*}{ Sulina } & Mean & 640421.59 & 526092.55 & 526190.95 \\
\hline & $\mathrm{N}$ & 76 & 85 & 97 \\
\hline & Sum & 48672041 & 44717867 & 51040522 \\
\hline & $\%$ of Total N & $1.60 \%$ & $1.70 \%$ & $1.70 \%$ \\
\hline & $\%$ of Total Sum & $0.60 \%$ & $0.50 \%$ & $0.60 \%$ \\
\hline \multirow{5}{*}{ C.A. Rosetti } & Mean & 598143.5 & 1495679 & 1982439.5 \\
\hline & $\mathrm{N}$ & 2 & 2 & 2 \\
\hline & Sum & 1196287 & 2991358 & 3964879 \\
\hline & $\%$ of Total $\mathrm{N}$ & $0.00 \%$ & $0.00 \%$ & $0.00 \%$ \\
\hline & $\%$ of Total Sum & $0.00 \%$ & $0.00 \%$ & $0.00 \%$ \\
\hline \multirow{6}{*}{ Jurilovca } & Mean & 555577.61 & 537916.5 & 537080.45 \\
\hline & $\mathrm{N}$ & 46 & 50 & 66 \\
\hline & Sum & 25556570 & 26895825 & 35447310 \\
\hline & $\%$ of Total N & $1.00 \%$ & $1.00 \%$ & $1.20 \%$ \\
\hline & $\%$ of Total Sum & $0.30 \%$ & $0.30 \%$ & $0.40 \%$ \\
\hline & Mean & 182339.13 & 160586.22 & 149458.8 \\
\hline \multirow{6}{*}{ Murighiol } & Mean & 570554.32 & 413789.23 & 443583.23 \\
\hline & $\mathrm{N}$ & 56 & 73 & 79 \\
\hline & Sum & 31951042 & 30206614 & 35043075 \\
\hline & $\%$ of Total $\mathrm{N}$ & $1.20 \%$ & $1.40 \%$ & $1.40 \%$ \\
\hline & $\%$ of Total Sum & $0.40 \%$ & $0.40 \%$ & $0.40 \%$ \\
\hline & Mean & 1401867 & 1919351 & 1701422.29 \\
\hline \multirow{5}{*}{$\begin{array}{l}\text { Sfântu } \\
\text { Gheorghe }\end{array}$} & Mean & 521376.5 & 380259.27 & 362259.89 \\
\hline & $\mathrm{N}$ & 18 & 26 & 27 \\
\hline & Sum & 9384777 & 9886741 & 9781017 \\
\hline & $\%$ of Total N & $0.40 \%$ & $0.50 \%$ & $0.50 \%$ \\
\hline & $\%$ of Total Sum & $0.10 \%$ & $0.10 \%$ & $0.10 \%$ \\
\hline
\end{tabular}

Table. 2. Rate of profit on the territorial units of Tulcea County

\begin{tabular}{|l|r|r|r|r|}
\hline Locality & Turnover (lei) & \multicolumn{1}{c|}{$\begin{array}{c}\text { Operating } \\
\text { expenses (lei) }\end{array}$} & $\begin{array}{c}\text { Operating } \\
\text { revenues (lei) }\end{array}$ & \multicolumn{1}{c|}{$\begin{array}{c}\text { Profit rate } \\
(\%)\end{array}$} \\
\hline Sulina & 48.672 .041 & 44.717 .867 & 51.040 .522 & 12,99 \\
\hline C.A. Rosetti & 1.196 .287 & 2.991 .358 & 3.964 .879 & 81,37 \\
\hline Jurilovca & 25.556 .570 & 26.895 .825 & 35.447 .310 & 33,46 \\
\hline Murighiol & 31.951 .042 & 30.206 .614 & 35.043 .075 & 15,13 \\
\hline Sfântu Gheorghe & 9.384 .777 & 9.886 .741 & 9.781 .017 & Pierdere \\
\hline
\end{tabular}




\section{sciendo}

118 Ovidius University Annals Series: Civil Engineering, Year 21, 2019

The profit is the reason for being of each entity and has the power to synthesize the quantitative and qualitative aspects of the economic processes, having a great power to reveal the economic reality. Figure 1 shows a comparative analysis, at the level of the territorial units on the coastal zone, the profit rate in 2018 (Table 2), highlighting aspects regarding the efficiency of the resources invested.

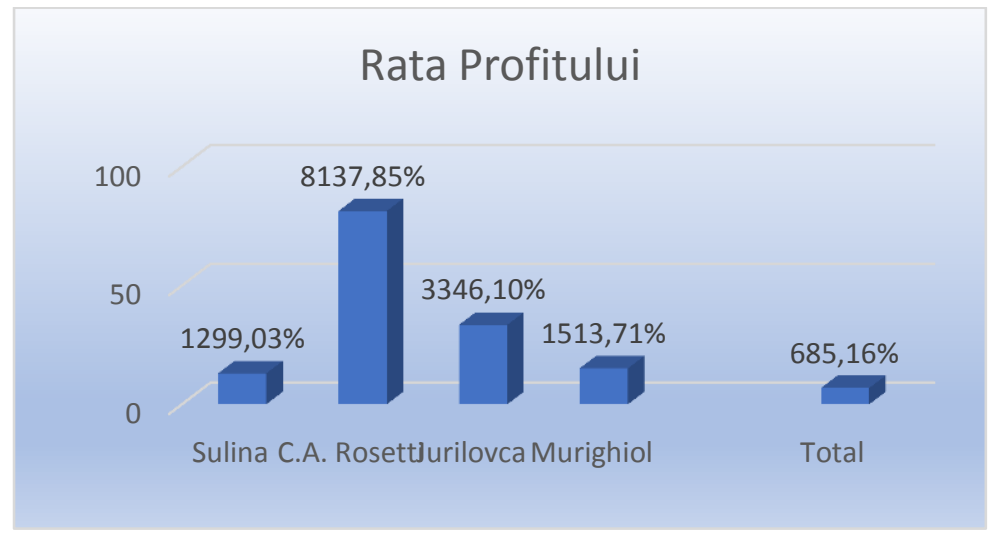

Fig. 1. The histogram of profit rate in 2018

Through it you can track how to use the factors of production, and its oscillations are essential elements in the analysis-diagnosis and evaluation of a company. The operating profit, the one that was used in our analysis, is calculated as the difference between the operating income and the operating expenses.

\section{RESULTS AND SIGNIFICANCES}

The turnover is essential for appreciating the company's place in its sector of activity, its position on the market, its ability to launch, to develop different activities in an efficient manner. This is the fundamental indicator of the activity volume of the economic agent and it is not missing from any system of indicators used in performance analysis. By analyzing the turnover, the aim is to obtain information related to the place and market position of the respective company, the ability of the company to diversify its activities and to self-finance, economic performances, the main sources of income and their stability, as well as the foreseeable evolution of these sources in the near future. "An indicator of dimensioning the activity, the turnover allows, by reference to the sectoral turnover or of the main competitor, the assessment of the place of the company in its sector of activity, of its market share. Depending on this positioning and the competitive environment, appropriate strategic decisions can be taken" [4].

The variation of the turnover is affected both directly and indirectly on the entire system of economic-financial indicators of a company but also on those that position it in a certain competitive environment. Knowing the implications of turnover, the mechanism by which it competes to improve the performance of the enterprise is useful in substantiating the operational decisions and those regarding the strategic orientation of the enterprise.

At the level of the administrative-territorial units analyzed, as it can be seen Figure 2, the largest volume of turnover was registered in the locality of Sulina (48.672.041 lei), followed by the locality of Murighiol (31.951.042 lei). 


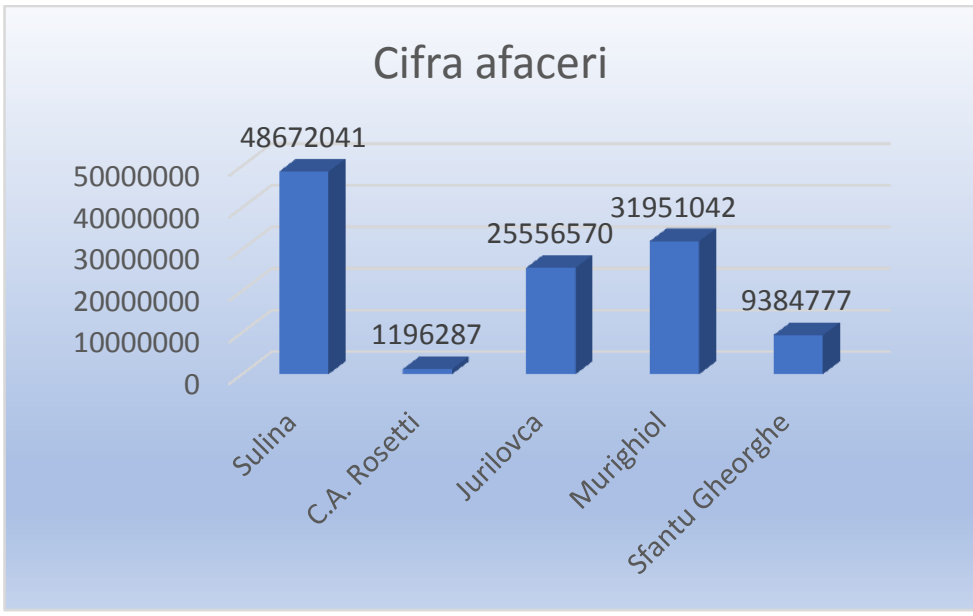

Fig. 2. The histogram of turnover

The operating revenues include revenues from the sale of products, works performed or services provided, revenues from stored production, revenues from fixed assets, revenues from operating grants, other operating revenues.

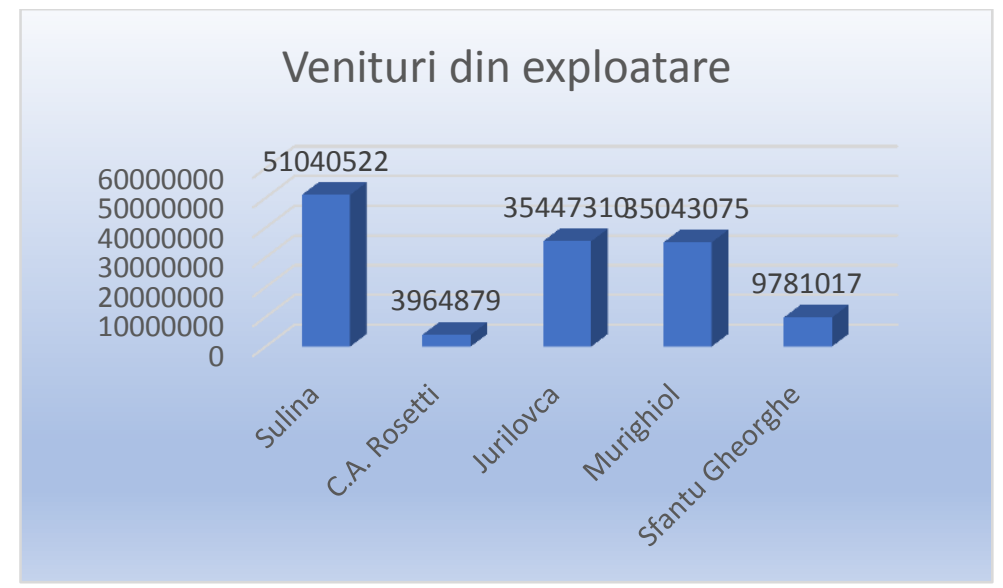

Fig. 3. The histogram of operating revenues

In terms of revenues and expenses, as shown in Figure 3, the highest level is recorded in the town of Sulina (51.040.522 lei, respectively 44.717 .867 lei), followed by Jurilovca (35.447.310 lei, respectively 26.895.825 lei) and Murighiol (35.043.075 lei, respectively 30.206.614 lei). These absolute levels of the indicators are not relevant in terms of performance, the profit rate highlighting another hierarchy: C.A. Rosetti, Jurilovca, Murighiol, and Sulina. The inclusion in the spatial comparison of C.A. Rosetti locality is quite debatable, considering the 2 companies that appear registered. The towns of Jurilovca and Murighiol are noticeable from this point of view. However, the localities of Jurilovca and Murighiol stand out from this point of view, achieving profit rates of $33.46 \%$ and $15.13 \%$ respectively. The only locality where we observe loss in the overall economic activity is Sfântu Gheorghe. 


\section{sciendo}

120 Ovidius University Annals Series: Civil Engineering, Year 21, 2019

\section{CONCLUSION}

The case study of this paper presents the analysis of the economic performances at territorial level of the localities in the coastal area of Tulcea County with the help of indicators: turnover, operating revenues, operating expenses and profitability rate.

According to the analysis, in four of the five areas analyzed, the economic activity is profitable, a single locality, namely Sfântu Gheorghe has registered losses in 2018.

This short X-ray analysis of the results obtained by these territorial units, and further, by each company operating in the respective area, can lead to three strategic orientations: development strategies, maintenance strategies and activity mitigation strategies. The strategy shows us how the entity can create value for society. It is not a discourse at all, but it guides the behaviors, the knowledge and the decisions towards a common objective: the creation of value. We live in a competitive economic system where the value is not realized unless the organization finds customers on the market. Therefore, the strategy must aim not only at creating this value, but also at recognizing it on the market, for the superiority of its own value over the other results in the competitive environment [4], [7].

\section{ACKNOWLEDGMENTS}

This work has been supported by the European Commission through the European Maritime and Fisheries Fund, Cross-border Maritime Spatial Planning for Black Sea Bulgaria and Romania (MARSPLAN-BS II), EASME/EMFF/2018/1.2.1.5/01/SI2.806725MARSPLAN-BS II.

\section{REFERENCES}

[1] Aivaz, K. (2007), Statistică Economică, Editura Muntenia, p. 329

[2] Aivaz, K. (2007), Econometrie-studii de caz, Editura Muntenia, p. 99

[3] Field, A. (2009), Discovering Statistics Using SPSS, Sage Publications Ltd., London.

[4] Petcu, M. (2009), Analiza Economico-Financiară a Întreprinderii, Editura Economică, Bucureşti. [5] Petrişor, A.-I. (2017), A diversity-based approach to the spatial development of socioecological systems, Urbanism. Architecture. Constructions, vol. 8, No.2, pp. 143-162.

[6] Petrişor, A.-I. (2016), Assessment of the long-term effects of global changes within the Romanian natural protected areas, Vol. 7, Issue 3, pp. 759-770.

[7] Vâlceanu, Gh., Robu, V. (2005), Georgescu, N., Analiza economico-financiară, ed.a-IIa, Editura Economică, Bucureşti.

\section{Note:}

\footnotetext{
Kamer-Ainur Aivaz - Ovidius University of Constanta, Bd. Mamaia nr. 124, 900356-Constanta, Romania (corresponding author to provide phone: +40-241-619040; fax: +40-241-618372; e-mail: aivaz_kamer@yahoo.com).

Dragoş-Florian Vintilă - Ovidius University of Constanta, Bd. Mamaia nr. 124, 900356-Constanta, Romania (e-mail: vdragos@univ-ovidius.ro).

Mari-Isabella Stan - Ovidius University of Constanta, Bd. Mamaia nr. 124, 900356-Constanta, Romania (e-mail: stanisabella@yahoo.com).

Ionela Ionitiu - Ovidius University of Constanta, Bd. Mamaia nr. 124, 900356-Constanta, Romania (email: ionelaionitiu@yahoo.com).

Diana-Doina Tenea - Ovidius University of Constanta, Bd. Mamaia nr. 124, 900356-Constanta, Romania (e-mail: dianat@univ-ovidius.ro).
} 